Jurnal Akuntansi dan Perpajakan, 6(1): 1-12, 2020

http://jurnal.unmer.ac.id/index.php/ap

\title{
Pemanfaatan Dana Desa Dalam Pemberdayaan Masyarakat Pada Desa Kopeng, Kecamatan Getasan, Kabupaten Semarang
}

\author{
Christian Kenny Alexander Wuisan¹, Aprina Nugrahesthy Sulistya Hapsari² \\ 1 Universitas Kristen Satya Wacana, Jl. Diponegoro 52-60, Salatiga, 50711, Indonesia \\ 2 Universitas Kristen Satya Wacana, Jl. Diponegoro 52-60, Salatiga, 50711, Indonesia
}

Keywords:

community empowerment; utilization of village fund; village funds

\section{Kata Kunci:}

dana desa, pemanfaatan dana desa, pemberdayaan masyarakat

\begin{abstract}
This study is intended to determine the use or utilization of village funds in Kopeng Village, especially in the field of community empowerment. The purpose of this study is to explain the allocation of village funds used for community empowerment in Kopeng Village, because according to government regulations the purpose of disbursing village funds is to help improve the village economy by empowering the community and not solely for village operational activities. Data collection methods in this study use descriptive qualitative methods. The data used in this study are primary data obtained from interviews and supported by evidence through documentation. Interviews were conducted with resource persons related to the research topic, namely village officials. Furthermore, the data collected will be analyzed into several stages, namely data reduction, triangulation, data presentation, and drawing conclusions. The results of research conducted in Kopeng Village show that the utilization of village funds for empowerment and community development is still not optimal because it is still focused on the field of development, especially infrastructure.
\end{abstract}

\footnotetext{
ABSTRAK

Penelitian ini meneliti penggunaan atau pemanfaatan dana desa di Desa Kopeng khususnya pada bidang pemberdayaan masyarakat. Tujuan penelitian ini adalah untuk memaparkan tentang alokasi pemanfaatan dana desa untuk pemberdayaan masyarakat di Desa Kopeng. Sesuai dengan peraturan pemerintah tujuan dikucurkannya dana desa adalah untuk membantu meningkatkan perekonomian desa dengan pemberdayaan masyarakat dan tidak semata-mata untuk kegiatan operasional desa. Metode pengumpulan data menggunakan metode deskriptif kualitatif. Data yang digunakan adalah data primer yang diperoleh dari wawancara dan didukung dengan bukti dokumentasi. Wawancara dilakukan terhadap narasumber yang terkait dengan topik penelitian yaitu aparat desa. Selanjutnya data yang telah terkumpul dianalisis kedalam beberapa tahapan, yaitu reduksi data, triangulasi, penyajian data, dan penarikan kesimpulan. Hasil penelitian di Desa Kopeng menunjukkan bahwa pemanfaatan dana desa untuk pemberdayaan dan pembinaan masyarakat masih belum optimal karena masih berfokus pada bidang pembangunan, khususnya infrastruktur.
} 


\section{PENDAHULUAN}

Desa merupakan bagian terkecil dari struktur pemerintahan di Indonesia yang dihuni oleh sekelompok masyarakat dan diakui sepenuhnya oleh hukum. Sekarang ini, pemerintah melihat desa sebagai bagian penting dalam pembangunan dan peningkatan kesejahteraan masyarakat Indonesia (Kementrian Keuangan Republik Indonesia 2017). Hal ini didukung dengan telah dikeluarkannya Undang-Undang Nomor 6 Tahun 2014 tentang Desa (Pemerintah Republik Indonesia 2014). Melalui kebijakan yang telah dibuat tersebut, maka desa diberi kewenangan oleh pemerintah untuk memaksimalkan potensi desa dengan tujuan untuk menyejahterakan masyarakatnya. Dalam rangka untuk memaksimalkan potensi desa di Indonesia, pemerintah memberikan bantuan berupa dana desa. Hal ini sesuai dengan Peraturan Pemerintah Nomor 8 Tahun 2016 tentang Dana Desa yang merupakan bagian dari APBN (Peraturan Pemerintah 2016). Dana Desa telah dikucurkan pemerintah dari tahun 2015 sampai dengan tahun 2018 telah mencapai Rp187,7 triliun (Ray Jordan 2019).

Tabel 1. Kucuran Dana Desa dari Tahun 2015-2018

\begin{tabular}{|c|c|}
\hline Tahun & Jumlah Dana Desa \\
\hline 2015 & Rp20,7 triliun \\
\hline 2016 & Rp47 triliun \\
\hline 2017 & Rp60 triliun \\
\hline 2018 & Rp60 triliun \\
\hline
\end{tabular}

Sumber: Jordan (2019)

Tujuan diberikannya dana desa oleh pemerintah agar desa dapat secara otonom memberdayakan masyarakatnya dalam menanggulangi kemiskinan dan pengangguran serta meningkatkan sumber daya ekonomi seperti pembangunan infrastruktur, peningkatan dibidang pendidikan dan kesehatan. Namun, dalam kenyataanya dana desa yang diberikan oleh pemerintah masih belum dipergunakan dengan semestinya. Seperti terdapat 170 kasus korupsi yang menimbulkan kerugian terhadap negara sebesar Rp833 miliar selama tahun 2018 (Rifqi Aufal Sutisna 2019). Hal tersebut didukung dengan laporan dari Dirjen Perimbangan Keuangan Kementrian Keuangan yang menyatakan bahwa angka serapan terhadap anggaran dana desa masih rendah (Hendra Kusuma 2018). Angka serapan dana desa yang masih rendah ini ternyata peruntukkannya juga didominasi oleh pembangunan infrastruktur yang ditunjukkan dari laporan Kementerian Desa, Pembangunan Daerah Tertinggal dan Transmigrasi (Kemendes PDTT) yang mengatakan bahwa 91 persen penggunaan dana desa masih digunakan untuk pembangunan infrastruktur dan hanya 8 persen yang digunakan untuk pemberdayaan masyarakat (Bayu Hermawan 2016). Melihat fenomena rendahnya penyerapan dana desa untuk pemberdayaan masyarakat, maka pemerintah pusat mengambil kebijakan untuk melakukan pengurangan porsi pembangunan infrastruktur tahun 2018-2019 (Rakhmat Nur Hakim 2018).

Beberapa penelitian terdahulu terkait dengan pengelolaan dana desa dalam pemberdayaan masyarakat, antara lain penelitian yang menyatakan bahwa sebagian dari Alokasi Dana Desa (ADD) di Desa Wonorejo digunakan untuk biaya operasional bukan untuk pemberdayaan masyarakat (Putra, Pratiwi \& Suwondo 2015). Menurut penelitian dari Karimah, Saleh dan Wanusmawatie (2014) menunjukkan bahwa pengelolaan Alokasi Dana Desa di Desa Deket Kulon Kabupaten Lamongan secara administratif dan normatif sudah baik, namun dalam hal pemberdayaan masyarakatnya masih belum baik. Pemanfaatan anggaran atas dana desa di Desa Liwutung tidak berjalan sesuai dengan aturan yang telah ditetapkan oleh pemerintah dikarenakan alokasi anggaran dana desa sebesar 70 persen belum digunakan untuk pemberdayaan masyarakat (Selviana Emelinia Lengkey, Florence Daicy Lengkong 2016). Penelitian dari Crecensia Merry Wilar dan Johnny Hanny Posumah (2017) menyatakan bahwa pemerintah Desa Pinonobatuan Barat tidak terbuka dalam pengelolaan Alokasi Dana Desa sehingga masyarakat tidak tahu jumlah biaya yang digunakan untuk pemberdayaan masyarakat. Selain itu, penelitian dari Suparman, Kusnadi dan Haryono (2014) yang menunjukkan bahwa pelaksanaan dari Alokasi Dana Desa di Kabupaten Kayong Utara 
belum mengarah ke pengembangan sosial ekonomi masyarakatnya melainkan lebih mengarah ke pembangunan infrastruktur.

Penelitian ini memaparkan tentang alokasi pemanfaatan dana desa yang dipakai untuk pemberdayaan masyarakat di Desa Kopeng, dikarenakan sesuai dengan peraturan pemerintah tujuan dikucurkannya dana desa adalah untuk membantu meningkatkan perekonomian desa dengan pemberdayaan masyarakat dan tidak semata-mata untuk kegiatan operasional desa. Alasan pemberdayaan masyarakat karena selama 5 tahun terakhir ini dana desa yang digelontorkan oleh pemerintah sebesar Rp257 triliun lebih banyak digunakan untuk infrastruktur ketimbang pemberdayaan masyarakat, sehingga Presiden akan menaikkan dana desa untuk lima tahun kedepan sebesar Rp400 triliun yang akan difokuskan untuk pemberdayaan masyarakat desa (Lestari 2019).Selain itu, Desa Kopeng adalah salah satu desa di Kabupaten Semarang yang menerima dana desa dari pemerintah cukup besar yaitu Rp822.568.000,00 dan jumlah ini meningkat dari tahun sebelumnya.

Bagi Desa Kopeng, penelitian ini diharapkan dapat menunjukkan terkait alokasi pemanfaatan dana desa untuk tujuan pemberdayaan masyarakat. Bagi pemerintah, penelitian ini membantu memberikan informasi mengenai pemanfaatan dana desa yang bertujuan untuk pemberdayaan masyarakat. Bagi akademisi, penelitian ini dapat digunakan sebagai salah satu kajian yang berhubungan dengan pemanfaatan dana desa.

\section{METODE}

Penelitian dilakukan di Desa Kopeng, Kecamatan Getasan, Kabupaten Semarang. Penelitian ini menggunakan metoda deskriptif kualitatif. Data yang digunakan adalah data primer yang diperoleh dari wawancara dan didukung dengan bukti dokumentasi. Wawancara dilakukan dengan narasumber yang terkait dengan topik penelitian yaitu aparat desa. Bukti dalam penelitian ini dapat berupa gambar, foto, maupun dokumen terkait.

Data yang berupa hasil wawancara dan pengumpulan dokumen atau bukti, selanjutnya dianalisis dengan beberapa tahapan yaitu reduksi data, triangulasi, penyajian data, dan penarikan kesimpulan. Reduksi data merupakan tahap untuk menyederhanakan atau mengerucutkan data dan informasi yang telah diperoleh, sehingga memudahkan peneliti dalam menarik kesimpulan. Data yang tidak sesuai dengan topik penelitian mengenai pemanfaatandana desa dalam pemberdayaan masyarakat di Desa Kopeng dihilangkan. Tahap kedua yaitu triangulasi, yang merupakan tahap untuk melihat keabsahan dari data tersebut. Triangulasi ini akan menunjukan data yang diperoleh berasal dari narasumber yang tepat atau tidak dengan didukung oleh bukti foto, gambar atau bukti lainnya. Tahap selanjutnya adalah penyajian data. Tahap ini merupakan gabungan dari dua tahap selanjutnya yang disusun dengan teks naratif, grafik maupun tabel yang mendeskripsikan data tersebut. Data yang disajikan merupakan data yang sah dengan disertai bukti terkait. Setelah melakukan penyajian data, tahap terakhir adalah penarikan kesimpulan yang berupa rangkuman dari keseluruhan hasil dalam penelitian yang telah dilakukan. Kesimpulan yang ingin dicapai oleh peneliti adalah tercapainya tujuan penelitian pemanfaatan dana desa dalam pemberdayaan masyarakat desa di Desa Kopeng. 


\section{HASIL}

Desa Kopeng dipimpin oleh seorang Kepala Desa yang dibantu oleh Sekretaris Desa. Sekretaris Desa dibantu oleh Kaur Keuangan serta Kaur Umum dan Perencanaan untuk melaksanakan kegiatan perbendaharaan. Kepala Desa juga membawahi Kasi Pemerintahan, Kasi Kesejahteraan Rakyat (Kesra) dan Kasi Pelayanan Hukum, serta 9 (sembilan) orang Kepala Dusun (Kadus).

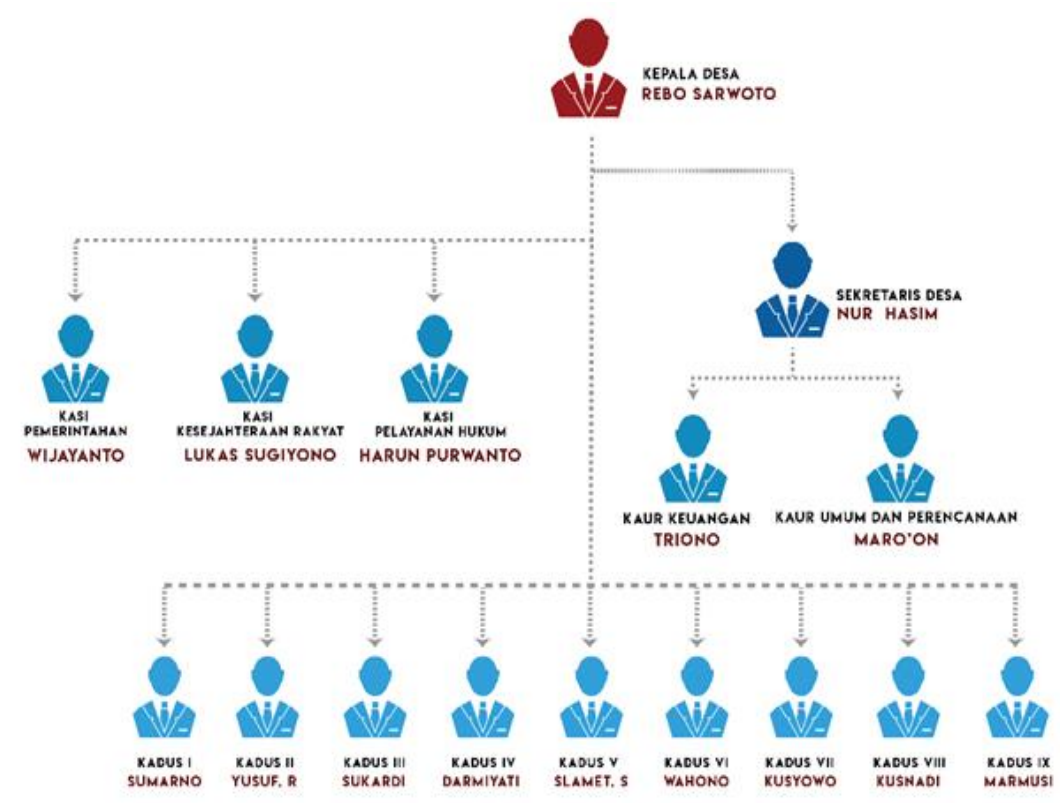

Gambar 1. Perangkat Desa Kopeng

Desa Kopeng terdiri atas 9 (sembilan) wilayah Kepala Dusun (Kadus) dengan total penduduk sebanyak 8.104 yang terdiri atas 4.075 penduduk laki-laki dan 4.029 penduduk perempuan. Desa Kopeng berada pada ketinggian 1700 meter diatas permukaan laut. Desa Kopeng ini memiliki jenis tanah yang cocok digunakan untuk melakukan kegiatan pertanian.

Berdasarkan pertimbangan kondisi dan permasalahan serta kebutuhan yang diperlukan oleh masyarakat Desa Kopeng maka disusun visi yaitu “Terwujudnya Kepala Desa Kopeng Kecamatan Getasan Kabupaten Semarang yang Mandiri, Tertib, dan Sejahtera." yang memiliki penjelasan sebagai berikut: mandiri yang artinya mampu mewujudkan kehidupan yang sejajar, sederajat serta saling berinteraksi dengan daerah lain dengan mengandalkan pada kemampuan dan kekuatan sendiri. Selanjutnya, tertib yang berarti mampu mewujudkan perilaku aparatur pemerintah dan masyarakat yang selalu berpegang teguh pada aturan dan norma-norma yang berlaku dalam bermasyarakat dan bernegara. Terakhir, sejahtera yang artinya mampu mewujudkan kondisi masyarakat yang terpenuhi hak-hak dasarnya dari aspek kesehatan, pendidikan, dan ekonomi yang ditandai dengan meningkatnya tingkat Indeks Pembangunan Manusia (IPM), kebebasan dalam kehidupan beragama dan bernegara, serta menurunnya angka kemiskinan.

Untuk mewujudkan visi tersebut, maka ada beberapa misi yang harus dilakukan sebagai berikut: (1) Meningkatkan kualitas SDM yang beriman dan bertaqwa kepada Tuhan Yang Maha Esa, berbudaya, serta menguasai ilmu pengetahuan dan teknologi, (2) Mengembangkan produk unggulan berbasis potensi lokal yang sinergi dan berdaya saing serta berwawasan lingkungan untuk menciptakan lapangan pekerjaan dan peningkatan pendapatan, (3) Menciptakan pemerintahan yang katalistik dan dinamis dengan mengedepankan prinsip good governance didukung oleh kelembagaan yang efektif dan kinerja aparatur yang kompeten, serta pemanfaatan teknologi informasi, (4) Menyediakan infrastruktur daerah yang merata guna mendukung peningkatan kualitas pelayanan dasar dan percepatan pembangunan, (5) Mendorong terciptanya partisipasi dan kemandirian masyarakat, kesetaraan dan keadilan gender serta perlindungan anak di 
semua bidang pembangunan, (6) Mendorong terciptanya pengelolaan sumber daya alam dan lingkungan hidup dengan tetap menjaga kelestariannya.

\section{Pemanfaatan Dana Desa dalam Pemberdayaan dan Pembinaan Masyarakat}

Dana desa di Desa Kopeng dialokasikan berdasarkan rancangan program kerja yang sebelumnya telah disusun oleh kepala desa untuk satu periode. Rancangan program kerja tercantum dalam RPJMDes yang disusun oleh kepala desa dengan mempertimbangkan kondisi dan kebutuhan desa, serta diurutkan berdasarkan skala prioritas. RPJMDes Desa Kopeng disusun setiap 6 (enam) tahun sekali sesuai masa jabatan kepala desa dalam satu periode, untuk mempermudah dan memberikan arah kebijakan program serta prioritas pembangunan dan landasan serta pedoman kebijakan operasional desa yang ingin dicapai.

RPJMDes yang telah disetujui dan sesuai dengan hasil MusRenBangDes (Musyawarah Perencanaan Pembangunan Desa) akan menjadi dasar dalam pembuatan APBDes dengan memetakan visi misinya terkait dengan 4 bidang, yaitu bidang penyelenggaraan pemerintahan desa, bidang pelaksanaan pembangunan desa, bidang pembinaan kemasyarakatan dan bidang pemberdayaan masyarakat. Bidang penyelenggaraan pemerintahan meliputi kegiatan-kegiatan yang bergubungan dengan kegiatan dan rutinitas pemerintahan desa, antara lain: penetapan dan penegasan batas desa, pendataan desa, penyusunan tata ruang desa, penyelenggaraan musyawarah desa, dan pengelolaan informasi desa. Bidang pelaksanaan pembangunan desa meliputi kegiatan yang bertujuan untuk meningkatkan infrastruktur, kondisi bangunan desa, dan kegiatan lain yang bertujuan untuk meningkatkan kemudahan akses desa, antara lain: pembangunan serta pemanfaatan infrastruktur, pembangunan sarana dan prasarana, lumbung desa, gudang pendingin, dan kandang ternak. Bidang pembinaan kemasyarakatan meliputi kegiatan yang bertujuan meningkatkan nilai sosial dalam masyarakat, antara lain: pembinaan lembaga kemasyarakatan, pembinaan kerukunan umat beragama, pembinaan kesenian dan sosial budaya, dan pembinaan lembaga adat. Bidang pemberdayaan masyarakat maliputi kegiatan yang bertujuan untuk meningkatkan kesejahteraan masyarakat dari segi ekonomi. Melalui program pemberdayaan masyarakat, diharapkan mampu meningkatkan kualitas hidup dan kemandirian dengan mengadakan pelatihan-pelatihan keterampilan, sehingga masyarakat mampu menghasilkan barang dan jasa untuk menambah penghasilan. Contoh kegiatan di bidang pemberdayaan masyarakat antara lain: kelompok tani, kelompok perempuan, kelompok usaha ekonomi produktif, pendidikan, pelatihan usaha, dan pelatihan teknologi.

APBDes Desa Kopeng sampai pada tahun 2019, masih berfokus pada pengembangan infrastruktur daripada pemberdayaan masyarakat dengan persentase sebesar $80 \%$ untuk infrastruktur dan $20 \%$ pada pemberdayaan masyarakat. Infrastruktur dinilai penting dan perlu untuk didahulukan untuk menunjang laju perekonomian warga Desa Kopeng. Hal ini seperti yang dikatakan oleh Pak TO selaku kaur keuangan:

"Kalau persentase dana desa itu sendiri sementara masih $20 \%$ pada pemberdayaan masyarakat dan $80 \%$ untuk infrastruktur dari tahun 2015 sampai sekarang."

Berdasarkan APBDes tahun anggaran 2017, 2018, dan 2019, bahwa total jumlah anggaran di tahun 2017 sebesar Rp 2.048.223.500 sebesar, di tahun 2018 mengalami penurunan total jumlah anggaran menjadi sebesar $\mathrm{Rp}$ 1.777.305.862 dan di tahun 2019 anggaran kembali meningkat menjadi sebesar Rp 2.115.709.349,00. Gambar 2 (dua) menunjukkan perubahan total anggaran dari tahun 2017 hingga 2019. 
Total Anggaran

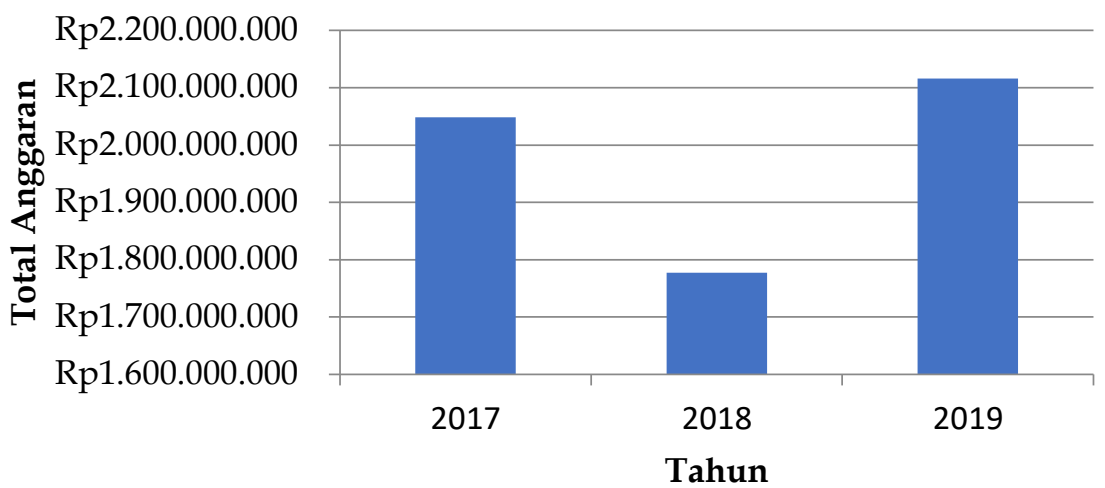

Gambar 2. Total Anggaran Pendapatan dan Belanja Desa Kopeng Tahun 2017,2018, 2019

Pada tahun 2017, anggaran dibidang penyelenggaraan pemerintahan desa sebesar Rp587.242.000, bidang pelaksanaan pembangunan desa sebesar Rp758.493.500, bidang pembinaan kemasyarakatan sebesar Rp 37.635.000 dan pemberdayaan masyarakat sebesar Rp 664.835.000. APBDes tahun anggaran 2017 disajikan dalam Tabel 2.

Tabel 2. Anggaran Pendapatan dan Belanja Desa Kopeng Tahun Anggaran 2017

\begin{tabular}{|c|c|c|c|}
\hline Bidang & Belanja & Ang & garan \\
\hline $\begin{array}{c}\text { Penyelenggaraan } \\
\text { Pemerintahan Desa }\end{array}$ & Penghasilan tetap dan tunjangan & $\mathrm{Rp}$ & 362.200 .000 \\
\hline \multirow{4}{*}{$29 \%$} & Operasional perkantoran & $\mathrm{Rp}$ & 132.343 .500 \\
\hline & Operasional BPD & $\mathrm{Rp}$ & 15.400 .000 \\
\hline & Operasional RT/RW & $\mathrm{Rp}$ & 32.000 .000 \\
\hline & Premi asuransi kesehatan dan ketenagakerjaan & $\mathrm{Rp}$ & 45.298 .500 \\
\hline $\begin{array}{c}\text { Pelaksanaan Pem- } \\
\text { bangunan Desa }\end{array}$ & Rehab lanjutan Kantor Kepala Desa & $\mathrm{Rp}$ & 108.493 .500 \\
\hline \multirow{2}{*}{$37 \%$} & Pembangunan betonisasi jalan poros desa & $\mathrm{Rp}$ & 400.000 .000 \\
\hline & Pembangunan betonisasi jalan lingkar Sidomukti & $\mathrm{Rp}$ & 250.000 .000 \\
\hline $\begin{array}{c}\text { Pembinaan Kemasyara- } \\
\text { katan }\end{array}$ & Sarpras penanggulangan bencana desa (LINMAS) & $\mathrm{Rp}$ & 10.653 .000 \\
\hline \multirow{2}{*}{$2 \%$} & Sosialisasi dan pembinaan WPA & $\mathrm{Rp}$ & 12.000 .000 \\
\hline & Peralatan kelompok kesenian & $\mathrm{Rp}$ & 15.000 .000 \\
\hline $\begin{array}{c}\text { Pemberdayaan } \\
\text { Masyarakat }\end{array}$ & Bantuan kesejahteraan pendidik PAUD dan TK & $\mathrm{Rp}$ & 15.000 .000 \\
\hline \multirow{6}{*}{$32 \%$} & Bantuan Posyandu & $\mathrm{Rp}$ & 4.000 .000 \\
\hline & Operasional PKK & $\mathrm{Rp}$ & 30.000 .000 \\
\hline & Kegiatan pelestarian nilai-nilai budaya & $\mathrm{Rp}$ & 340.580 .000 \\
\hline & Kelas ibu hamil & $\mathrm{Rp}$ & 11.255 .000 \\
\hline & PMT Posyandu & $\mathrm{Rp}$ & 24.000 .000 \\
\hline & Bedah rumah 12 unit & $\mathrm{Rp}$ & 240.000 .000 \\
\hline Total & & $\mathrm{Rp}$ & .048 .223 .500 \\
\hline
\end{tabular}

Sumber: Data Primer, Desa Kopeng (2019) 
Pada tahun 2018, anggaran dibidang penyelenggaraan pemerintahan desa sebesar Rp920.829.724, bidang pelaksanaan pembangunan desa sebesar Rp808.702.000, bidang pembinaan kemasyarakatan sebesar Rp 140.489.000 dan pemberdayaan masyarakat sebesar Rp 167.350.000. APBDes tahun anggaran 2018 disajikan dalam Tabel 3.

Tabel 3. Anggaran Pendapatan dan Belanja Desa Kopeng Tahun Anggaran 2018

\begin{tabular}{|c|c|c|}
\hline Bidang & Belanja & Anggaran \\
\hline $\begin{array}{l}\text { Penyelenggaraan } \\
\text { Pemerintahan Desa }\end{array}$ & Pembayaran penghasilan tetap dan tunjangan & Rp 660.764 .862 \\
\hline \multirow{9}{*}{$52 \%$} & Kegiatan operasional kantor desa & Rp 85.226.400 \\
\hline & Kegiatan operasional BPD & $\operatorname{Rp} 21.400 .000$ \\
\hline & Kegiatan operasional RT/RW & $\operatorname{Rp} 32.000 .000$ \\
\hline & $\begin{array}{l}\text { Kegiatan peningkatan sarana dan prasarana per- } \\
\text { kantoran }\end{array}$ & Rp 48.500.000 \\
\hline & Kegiatan peningkatan administrasi pemerintahan & Rp 5.000 .000 \\
\hline & Kegiatan BPJS kesehatan/ jaminan kesehatan & $\operatorname{Rp} 13.464 .000$ \\
\hline & Kegiatan BPJS ketenagakerjaan & Rp 25.214.400 \\
\hline & $\begin{array}{l}\text { Kegiatan pengelolaan keuangan desa dan ap- } \\
\text { likasi keuangan }\end{array}$ & 1.125 .062 \\
\hline & $\begin{array}{l}\text { Kegiatan pengisian perangkat desa dan lembaga } \\
\text { desa }\end{array}$ & $\operatorname{Rp} 28.135 .000$ \\
\hline $\begin{array}{l}\text { Pelaksanaan Pem- } \\
\text { bangunan Desa }\end{array}$ & $\begin{array}{l}\text { Kegiatan pembangunan, pemanfaatan, pemeli- } \\
\text { haraan sarana dan prasarana }\end{array}$ & Rp 765.202.000 \\
\hline $46 \%$ & Kegiatan penguatan permodalan BUMDes & Rp 43.500 .000 \\
\hline $\begin{array}{l}\text { Pembinaan Kemasyara- } \\
\text { katan }\end{array}$ & Pembinaan kerukunan umat beragama & \multirow[t]{2}{*}{ Rp $\quad 4.989 .000$} \\
\hline \multirow[t]{7}{*}{ (3) } & $\begin{array}{l}\text { Pembinaan pemberdayaan kesejahteraan } \\
\text { keluarga }\end{array}$ & \\
\hline & Pembinaan Pos Pelayanan Terpadu & Rp 23.440 .000 \\
\hline & Pembinaan PAUD/TK & Rp 15.000 .000 \\
\hline & $\begin{array}{l}\text { Pembinaan kader pemberdayaan masyarakat } \\
\text { desa }\end{array}$ & Rp $\quad 5.000 .000$ \\
\hline & Pembinaan badan pemberdayaan perempuan & Rp 46.700 .000 \\
\hline & Pembinaan masyarakat peduli AIDS & Rp 12.000 .000 \\
\hline & Kelas ibu hamil & Rp 3.360 .000 \\
\hline $\begin{array}{l}\text { Pemberdayaan Masyara- } \\
\text { kat }\end{array}$ & $\begin{array}{l}\text { Kegiatan rehab Rumah Tidak Layak Huni } \\
\text { (RTLH) }\end{array}$ & Rp167.350.000 \\
\hline \multicolumn{3}{|l|}{$9 \%$} \\
\hline Total: & & 1.777 .305 .862 \\
\hline
\end{tabular}

Sumber: Data Primer, Desa Kopeng (2019) 
Pada tahun 2019, anggaran dibidang penyelenggaraan pemerintahan desa sebesar Rp723.263.799, bidang pelaksanaan pembangunan desa sebesar Rp1.084.380.000, bidang pembinaan kemasyarakatan sebesar Rp 272.565.550 dan pemberdayaan masyarakat sebesar Rp 35.500.000. APBDes tahun anggaran 2019 disajikan dalam Tabel 4.

Tabel 4. Anggaran Pendapatan dan Belanja Desa Kopeng Tahun Anggaran 2019

\begin{tabular}{|c|c|c|c|}
\hline Bidang & Belanja & \multicolumn{2}{|c|}{ Anggaran } \\
\hline $\begin{array}{l}\text { Penyelenggaraan } \\
\text { Pemerintahan Desa }\end{array}$ & $\begin{array}{l}\text { Penyelenggaraan belanja Siltap, tunjangan, dan } \\
\text { operasional pemerintahan desa }\end{array}$ & $\mathrm{Rp}$ & 474.822 .799 \\
\hline \multirow{3}{*}{$34 \%$} & Penyediaan sarana prasarana pemerintahan desa & $R p$ & 123.265 .000 \\
\hline & $\begin{array}{l}\text { Penyelenggaraan tata praja pemerintahan, } \\
\text { perencanaan, keuangan dan pelaporan }\end{array}$ & $\mathrm{Rp}$ & 118.176 .000 \\
\hline & Administrasi Pajak Bumi dan Bangunan (PBB) & $\operatorname{Rp}$ & 7.000 .000 \\
\hline $\begin{array}{l}\text { Pelaksanaan Pem- } \\
\text { bangunan Desa }\end{array}$ & Bidang pendidikan & $\mathrm{Rp}$ & 51.600 .000 \\
\hline \multirow{3}{*}{$51 \%$} & Bidang kesehatan & $\mathrm{Rp}$ & 56.840 .000 \\
\hline & Bidang pekerjaan umum dan penataan ruang & $\operatorname{Rp}$ & 731.890 .000 \\
\hline & Bidang kawasan pemukiman & $\operatorname{Rp}$ & 244.050 .000 \\
\hline $\begin{array}{l}\text { Pembinaan Kemasyara- } \\
\text { katan }\end{array}$ & $\begin{array}{l}\text { Penguatan dan peningkatan kapasitas tenaga } \\
\text { keamanan/ketertiban }\end{array}$ & $\mathrm{Rp}$ & 18.000 .000 \\
\hline \multirow[t]{7}{*}{, } & $\begin{array}{l}\text { Pelatihan/sosialisasi kepada masyarakat di bi- } \\
\text { dang hukum }\end{array}$ & $\mathrm{Rp}$ & 12.000 .000 \\
\hline & $\begin{array}{l}\text { Pembinaan grup kesenian dan kebudayaan ting- } \\
\text { kat desa }\end{array}$ & $\mathrm{Rp}$ & 20.000 .000 \\
\hline & $\begin{array}{l}\text { Penyelenggaraan festival kesenian, adat/ke- } \\
\text { budayaan, dan keagamaan }\end{array}$ & $\mathrm{Rp}$ & 25.000 .000 \\
\hline & Rehabilitasi sarana/prasarana kebudayaan & Rp & 100.000 .000 \\
\hline & $\begin{array}{l}\text { Penyelenggaraan pelatihan kepemudaan tingkat } \\
\text { desa }\end{array}$ & $\mathrm{Rp}$ & 10.000 .000 \\
\hline & $\begin{array}{l}\text { Rehabilitasi/peningkatan sarana dan prasarana } \\
\text { kepemudaan }\end{array}$ & $\mathrm{Rp}$ & 57.565 .550 \\
\hline & Pembinaan PKK & Rp & 30.000 .000 \\
\hline $\begin{array}{l}\text { Pemberdayaan Masyara- } \\
\text { kat }\end{array}$ & Peningkatan kapasitas aparatur desa & $\mathrm{Rp}$ & 5.500 .000 \\
\hline \multirow{2}{*}{ ( } & $\begin{array}{l}\text { Lain-lain kegiatan bidang peningkatan kapasitas } \\
\text { aparatur desa }\end{array}$ & $\mathrm{Rp}$ & 10.000 .000 \\
\hline & Dukungan penanaman modal & $R p$ & 20.000 .000 \\
\hline Total: & & $R p$ & 2.115 .709 .349 \\
\hline
\end{tabular}

Sumber: Data Primer, Desa Kopeng (2019) 
Berdasarkan APBDes tersebut, anggaran untuk bidang pembinaan dan pemberdayaan masyarakat terdapat di dua poin terbawah. Hal ini disebabkan karena fokus anggaran pada tahun-tahun tersebut adalah untuk infrastruktur dan pembangunan desa. Total anggaran yang digunakan juga tidak sebanyak yang digunakan dibidang pembangunan. Tabel 5 menunjukkan rangkuman dari anggaran bidang pembinaan dan pemberdayaan masyarakat selama tahun 2017, 2018, 2019.

Tabel 5. Anggaran Pendapatan dan Belanja Desa Kopeng Bidang Pembinaan dan Pemberdayaan Masyarakat

\begin{tabular}{|l|r|r|r|}
\hline & $\mathbf{2 0 1 7}$ & $\mathbf{2 0 1 8}$ & \multicolumn{1}{c|}{$\mathbf{2 0 1 9}$} \\
\hline $\begin{array}{l}\text { Pembinaan } \\
\text { Masyarakat }\end{array}$ & $\operatorname{Rp} 37.653 .000,00$ & $\operatorname{Rp~} 140489.000,00$ & $\operatorname{Rp} 272.565 .550,00$ \\
\hline $\begin{array}{l}\text { Pemberdayaan } \\
\text { Masyarakat }\end{array}$ & $\operatorname{Rp~} 664.835 .000,00$ & $\operatorname{Rp~} 167.350 .000,00$ & $\operatorname{Rp} 35.500 .000,00$ \\
\hline Total & $\operatorname{Rp~} 702.488 .000,00$ & $\operatorname{Rp} 307.839 .000,00$ & $\operatorname{Rp} 308.065 .550,00$ \\
\hline
\end{tabular}

Sumber: Data Primer, Desa Kopeng (2019)

Rata-rata penyerapan anggaran bidang pemberdayaan dan pembinaan masyarakat hanya sebesar 95\%. Perubahan kondisi lingkungan yang terjadi saat proses realisasi menjadi kendala yang menyebabkan tidak terserapnya anggaran 100\%. Hal ini seperti yang dikatakan oleh Pak NH selaku sekretaris desa:

"Kalau rata-rata, ya tidak bisa 100\%. Hanya 95\% saja dari anggaran. Kondisi lingkungan mempengaruhi, misalnya harga kemarin hasil survei tidak sama dengan harga saat realisasi. Ternyata lebih rendah."

\section{PEMBAHASAN}

Penelitian ini berfokus pada pemanfaatan dana desa pada pemberdayaan masyarakat. Setelah melakukan pengumpulan data di Desa Kopeng, pemberdayaan masyarakat yang dimaksud pada penelitian ini mencakup dua bidang sesuai RPJMDes, yaitu bidang pemberdayaan masyarakat dan bidang pembinaan kemasyarakatan. Penambahan bidang pembinaan masyarakat dipandang mampu memberikan kontribusi pada upaya meningkatkan kualitas hidup dan kemampuan masyarakat. Bidang pembinaan masyarakat yang bertujuan untuk meningkatkan nilai sosial masyarakat, mampu mendukung bidang pemberdayaan masyarakat yang bertujuan meningkatkan kualitas hidup masyarakat melalui perekonomian. Sebagai contoh, masyarakat yang memiliki nilai sosial tinggi akan mampu berkomunikasi dan bermasyarakat dengan baik. Keterampilan berkomunikasi akan memudahkan masyarakat merencanakan kegiatan ekonomi, misalnya bersama-sama mengelola pertanian, perkebunan, atau melakukan usaha secara berkelompok. Sehingga peneliti menambahkan bidang pembinaan desa pada penelitian ini.

Berdasarkan hasil wawancara, Desa Kopeng di tahun anggaran 2017, 2018, dan 2019 masih berfokus pada bidang pelaksanaan pembangunan desa. Kebutuhan pembangunan desa dianggap lebih mendesak dan penting. Sebagai contoh dari pembangunan desa adalah perbaikan struktur jalan dan pembangunan jalanjalan baru di Desa Kopeng, yang bertujuan agar mampu memenuhi kebutuhan akses transportasi masyarakat untuk melakukan kegiatan perekonomian, misalnya menjual hasil kebun, membeli kebutuhan pupuk, dan memasarkan hasil kebunnya (mata pencaharian Desa Kopeng sebagian besar perkebunan dan pertanian). Selain itu, penyediaan infrastruktur dan bangunan-bangunan penunjang lain bertujuan demi kepuasan masyarakat Desa Kopeng. Masyarakat seolah-olah belum merasakan adanya manfaat dari dana desa apabila belum ada bangunan secara fisik di desa mereka sebagai bukti adanya pembangunan. Hal ini seperti yang dikatakan oleh Pak Nur Hashim selaku sekretaris desa:

"Soalnya masyarakat itu kalau belum dibangun bangunan fisik belum merasakan adanya dana desa. makanya pembangunan dilakukan di awal mas"

Perbandingan persentase alokasi dana desa untuk bidang pelaksanaan pembangunan, bidang pembinaan dan pemberdayaan masyarakat disajikan pada Tabel 6. 
Tabel 6. Perbandingan Anggaran Bidang Pelaksanaan Pembangunan, Pembinaan Masyarakat, dan Pemberdayaan Masyarakat

\begin{tabular}{|l|r|r|r|}
\hline & $\mathbf{2 0 1 7}$ & $\mathbf{2 0 1 8}$ & \multicolumn{1}{|c|}{$\mathbf{2 0 1 9}$} \\
\hline $\begin{array}{l}\text { Pelaksanaan } \\
\text { Pembangunan }\end{array}$ & Rp 758.493.500,00 & Rp 808.702.000,00 & Rp 1.084.380.000,00 \\
\hline $\begin{array}{l}\text { Pembinaan } \\
\text { Masyarakat }\end{array}$ & Rp 37.653.000,00 & Rp 140 489.000,00 & Rp 272. 565.550,00 \\
\hline & Rp 664.835.000,00 & Rp 167.350.000,00 & $13 \%$ \\
\hline $\begin{array}{l}\text { Pemberdayaan } \\
\text { Masyarakat }\end{array}$ & $32 \%$ & $9 \%$ & Rp 35.500.000,00 \\
\hline & & $2 \%$ \\
\hline
\end{tabular}

Sumber: Data Primer, Desa Kopeng (2019)

Pada Tabel 6, dari tahun ke tahun, anggaran untuk bidang pelaksanaan pembangunan dan pembinaan masyarakat selalu meningkat. Peningkatan ini disebabkan karena fokus RPJMDes tahun 20172019 adalah di bidang pelaksanaan pembangunan. Sebelum bantuan dana desa diberikan dari pemerintah, Desa Kopeng belum memiliki infrastruktur, khususnya jalan yang baik. Desa Kopeng berada di dataran tinggi, sehingga memiliki struktur tanah yang lempengnya sering bergeser dan membuat keretakan di jalanjalan desa dan bangunan-bangunannya. APBDes untuk bidang pembinaan masyarakat juga mengalami peningkatan, walaupun bukan merupakan fokus utama dalam anggaran 2017, 2018, dan 2019. Anggaran yang terus meningkat menunjukkan bahwa bidang pelaksanaan pembangunan dan pembinaan masyarakatnya bagus dan berkembang, disertai dengan bertambahnya program-program untuk bidang tersebut.

Di sisi lain, persentasi anggaran bidang pemberdayaan masyarakat tahun 2017 sampai dengan 2019 justru mengalami penurunan. Penurunan ini disebabkan karena alokasi dana desa memang lebih difokuskan pada pelaksanaan pembangunan dan pembinaan masyarakat. Pada tahun 2017, persentasi pemberdayaan masyarakat mampu mencapai 32\% bahkan mendekati persentase dari bidang pelaksanaan pembangunan, yaitu 37\%. Hal ini disebabkan karena saat membuat RPJMDes, pemerintah desa sepakat ingin meningkatkan pemberdayaan masyarakat di tahun 2017 tersebut. Kebutuhan infrastruktur dan pembinaan masyarakat lebih mendesak untuk dipenuhi. Jalan-jalan desa belum semua mendapatkan perbaikan. Kegiatan pemberdayaan masyarakat juga dipandang penting untuk meningkatkan kemampuan masyarakat menciptakan peluang-peluang ekonomi. Namun, pada kenyataannya pada tahun 2017, bidang pemberdayaan masyarakat justru bukan bidang yang paling mendesak untuk segera terpenuhi sesuai pada periode RPJMDes, sehingga pemerintah desa memutuskan untuk mengalokasikan lebih banyak pada pelaksanaan pembangunan di tahun 2018 dan 2019. Sehingga keputusan perubahan persentase anggaran tidak hanya berdasarkan pada RPJMDes saja, tetapi juga didasarkan pada kebutuhan kondisional yang muncul dan mendesak untuk dipenuhi selama periode anggaran berjalan. Aparat desa akan melakukan pengamatan pada apa yang paling dibutuhkan masyarakat pada waktu tersebut serta kondisi yang terjadi di lapangan. Hal ini seperti yang dikatakan oleh Pak RS selaku kepala desa:

"Berubah itu sesuai kondisi saja. Apa yang harus diprioritaskan ya dilakukan. Tapi memang infrastruktur lebih diutamakan."

Salah satu sekolah yang terdapat di Desa Kopeng belum sepenuhnya terbantu dengan adanya dana desa sehingga sekolah masih mengandalkan biaya mandiri yang dikumpulkan dari orang tua siswa. Sekolah di Desa Kopeng berharap bantuan dari dana desa tetap diberikan oleh desa karena sekolah ini berada di wilayah desa dan anak-anak warga. Hal ini seperti yang dikatakan oleh Pak RM selaku kepala sekolah:

"Kalau disini sekolah memang belum mendapatkan bantuan dana desa, jadi semua dana yang digunakan untuk kegiatan sekolah didapatkan melalui biaya mandiri dari para orang tua siswa disini."

Realisasi anggaran rata-rata hanya sebesar 95\% saja. Hal ini disebabkan karena sulit untuk memperkirakan anggaran dengan tepat dan terjadi ketidakpastian di lapangan, baik dalam bentuk nominal maupun jumlah item yang dibutuhkan. Sebagai contoh penyediaan sarana sebagai pendukung pengadaan 
pelatihan menjahit, di hari berlangsungnya pelatihan, terjadi perubahan kebutuhan alat yang menyebabkan adanya sisa anggaran yang tidak terpakai. Contoh lain adalah pada kegiatan edukasi dalam pembibitan tanaman, anggaran tidak sepenuhnya terpakai. Sisa lebih anggaran juga disebabkan karena ada kekhawatiran jika realisasi melebihi anggaran. Hal ini seperti yang dikatakan oleh Pak NH selaku sekretaris desa:

"Kalau rata-rata, ya tidak bisa 100 persen. Hanya 95 persen saja dari anggaran. Kondisi lingkungan mempengaruhi, misalnya harga kemarin hasil survei tidak sama dengan harga saat realisasi. Ternyata lebih rendah. Misalnya pengadaan barang buat pelatihan, waktu hari H-nya berbeda. Lebih baik sisa dari pada kurang, soalnya kalau kurang desa sudah tidak memiliki dana untuk menutupi kekurangan tersebut."

Sisa 5 persen dari anggaran akan digunakan desa sebagai dana operasional sehari-hari, kebutuhan lain-lain, serta perjalanan dinas. Hal ini seperti yang dikatakan oleh Pak RS selaku kepala desa:

"Masuk operasional untuk membayar pengeluaran lain-lain, juga untuk perjalanan dinas."

Dari hasil analisis di atas, menunjukkan bahwa masyarakat sebenarnya membutuhkan peran desa untuk membantu menjalankan kegiatan-kegiatan tersebut, dari segi pendampingan maupun sumber dana. Sisa anggaran yang tidak terealisasikan, lebih baik dialokasikan pada kegiatan pemberdayaan dan pembinaan masyarakat yang masih kekurangan, dibandingkan digunakan untuk operasional desa.

Dalam rangka memenuhi kebutuhan masyarakat tersebut, peningkatan porsi persentase pada pemberdayaan masyarakat direncanakan akan mengalami peningkatan pada tahun 2020. Peningkatan ini diharapkan mampu menutupi kekurangan dana dan memberikan pelatihan sebagai bekal keterampilan di dunia kerja Hal ini seperti yang dikatakan oleh Pak TO selaku bendahara:

"Tahun 2020, itu pembangunan infrastruktur di desa Kopeng 90 persen sudah selesai sehingga setelah semua pembangunan selesai, selanjutnya pasti ada peningkatan porsi pada pemberdayaan masyarakat."

\section{SIMPULAN DAN SARAN}

Hasil dari penelitian yang dilakukan di Desa Kopeng menunjukkan bahwa pemanfaatan dana desa untuk pemberdayaan dan pembinaan masyarakat masih belum optimal karena masih berfokus pada bidang pembangunan, khususnya infrastruktur. Masyarakat juga merasakan dampak dari kurang optimalnya pemanfaatan dana desa. Selain melihat kesesuaian dengan RPJMDes, kenaikan atau penurunan persentasi anggaran didasarkan pada kebutuhan yang paling mendesak dan harus segera dipenuhi oleh desa, berdasarkan prioritas dan kesesuaian dengan RPJMDes. Rata-rata anggaran tidak sepenuhnya terserap, tetapi hanya 95\% saja, menyebabkan semakin kurang optimalnya pemanfaatan dana desa di Desa Kopeng.

Keterbatasan dalam penelitian ini adalah terbatasnya waktu dari aparat desa dan terbatasnya akses untuk dokumen-dokumen pendukung yaitu dokumen realisasi. Hal ini berdampak pada kesulitan menganalisis dan pencarian dokumen alternatif yang mampu mendukung analisis peneliti. Saran untuk penelitian selanjutya adalah melakukan penelitian dengan tahun amatan yang lebih luas, tidak berdasarkan hanya pada realisasi saja, dan melakukan observasi lebih dalam dengan membandingkan desa lainnya.

\section{DAFTAR PUSTAKA}

Bayu Hermawan 2016, Kemendes: 91 Persen Dana Desa Digunakan untuk Bangun Infrastruktur | Republika Online, <https://nasional.republika.co.id/berita/nasional/umum/16/12/25/oipdun354-kemendes91-persen-dana-desa-digunakan-untuk-bangun-infrastruktur>.

Crecensia Merry Wilar, Johnny Hanny Posumah, T.S. 2017, 'Pemberdayaan Masyarakat dalam Pemanfaatan Alokasi Dana di Desa Pinonobatuan Barat Kecamatan Dumoga Timur Kabupaten Bolaang Mongondow', Jurnal Administrasi Publik UNSRAT, pp. 1-7.

Hendra Kusuma 2018, Serapan Dana Desa Masih Rendah, viewed 19 February 2019, <https:/ / finance.detik.com/berita-ekonomi-bisnis/d-4303850/serapan-dana-desa-masihrendah?_ga=2.230069788.1892460752.1549870850-1394342107.1545917769>.

Karimah, F., Saleh, C. \& Wanusmawatie, I. 2014, 'Pengelolaan Alokasi Dana Desa Dalam Pemberdayaan Masyarakat', Jurnal Administrasi Publik (JAP), vol. 2, no. 4, pp. 597-602.

Kementrian Keuangan Republik Indonesia 2017, 'Buku Pintar Dana Desa', Buku Pintar Dana Desa, p. 113. 
Lestari, M. 2019, Mendes Minta Pemda Pakai Dana Desa untuk Pemberdayaan Ekonomi.

Pemerintah Republik Indonesia 2014, Undang-Undang Republik Indonesia Nomor 6 Tahun 2014 Tentang Desa.

Peraturan Pemerintah 2016, Peraturan Pemerintah Republik Indonesia Nomor 8 Tahun 2016 Tentang Perubahan Kedua atas Peraturan Pemerintah Nomor 60 Tahun 2014 Tentang Dana Desa yang Bersumber dari Anggaran Pendapatan dan Belanja Negara.

Putra, C.K., Pratiwi, R.N. \& Suwondo 2015, 'Pengelolaan Alokasi Dana Desa dalam Pemberdayaan Masyarakat Desa (Studi pada Desa Wonorejo Kecamatan Singosari Kabupaten Malang)’, Jurnal Administrasi Publik (JAP), vol. 1, no. 6, pp. 1203-12.

Rakhmat Nur Hakim 2018, Mendes Sebut Porsi untuk Infrastruktur dalam Dana Desa Diperkecil - Kompas.com, viewed 27 February 2019, <https://nasional.kompas.com/read/2018/11/14/18394271/mendessebut-porsi-untuk-infrastruktur-dalam-dana-desa-diperkecil>.

Ray Jordan 2019, Jokowi: 85 Persen Masyarakat Puas dengan Dana Desa, viewed 18 February 2019 , <https:/ / news.detik.com/berita/d-4371208/jokowi-85-persen-masyarakat-puas-dengan-danadesa?_ga=2.147181815.1732516825.1550506167-1394342107.1545917769>.

Rifqi Aufal Sutisna 2019, ICW: Program Dana Desa Rentan Dikorupsi Perangkat Daerah - News Liputan6.com, viewed 18 February 2019, <https://www.liputan6.com/news/read/3889995/icw-program-danadesa-rentan-dikorupsi-perangkat-daerah>.

Selviana Emelinia Lengkey, Florence Daicy Lengkong, S.R. 2016, 'Pemberdayaan Masyarakat dalam Pemanfaatan Alokasi Dana Desa di Desa Liwutung II Kecamatan Pasan Kabupaten Minahasa Tenggara', Jurnal Administrasi Publik UNSRAT, p. 302.

Suparman, Kusnadi, D. \& Haryono, D. 2014, ‘Implementasi Program Alokasi Dana Desa Di Kecamatan Sukadana Kabupaten Kayong Utara', Tesis PMIS-UNTAN-PSIAN, pp. 1-20. 